\title{
Dermoscopy of cutaneous horn of the nose
}

\section{Selma El Kadiri, Hanane Baybay, Rhizlane Chaoui, Zakia Douhi, Sara Elloudi, Fatima Zahra Mernissi}

Department of Dermatology, CHU Hassan II, Fez, Morocco

Corresponding author: Dr. Selma El Kadiri, E-mail: elkadiri-s@hotmail.com

Sir,

Cutaneous horn are hyperkeratotic projections of the skin which usually develop on sun-exposed areas. Their etiologies are variable [1]. We report a case of a 32-year old man presented with a 7 month increasing and itchy keratotic papule on the nose. Dermatological examination revealed a sessile and keratotic horn located in the right perinarinar region (Fig. 1). Dermoscopic evaluation found harpin vessels, black dots in combination with white-yellowish exophytic and keratotic projection pattern (Fig. 2). A complete excision was performed at the base and send for pathological review. Histopathological examination of biopsy specimens showed spiking epidermal, koilocytes in the superficial layer of the epidermis, columns of parakeratosis and dilated blood vessels in the dermal papillae. Features were conssitent with a warty horn and the patient was reassured.

Warts are common cause of consultation and are caused by human papillomavirus. They can occur in different areas and their clinical aspect is very variable from vulgaris wart, palmo-plantar warts and condolyma acuminata. Cutaneous horn are conical skin raised skin lesions composed of dead keratin [2]. It is difficult sometimes to differentiate warty horn from other causes like (squamous cell carcinoma, keratoacanthoma and trichilemmal carcinoma [3]. Dermoscopy of warts can found black dots corresponding to thrombosed vessels. The vascular structures are frequently dotted or linear. Hairpin vessels were reported in combination with keratotic projection like our case. They can be seen in other dermatosis as squamous cell carcinoma but they are surrounded by a whitish halo [4].

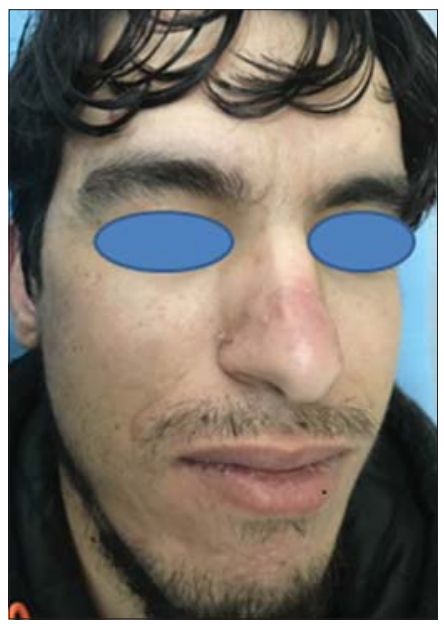

Figure 1: Clinical aspect of warty horn in the righ perinarinar region.

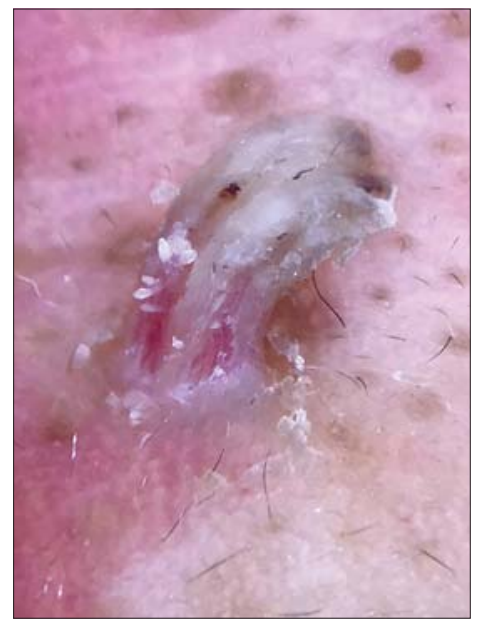

Figure 2: Dermoscopy of warty horn.

\section{Consent}

The examination of the patient was conducted according to the Declaration of Helsinki principles.

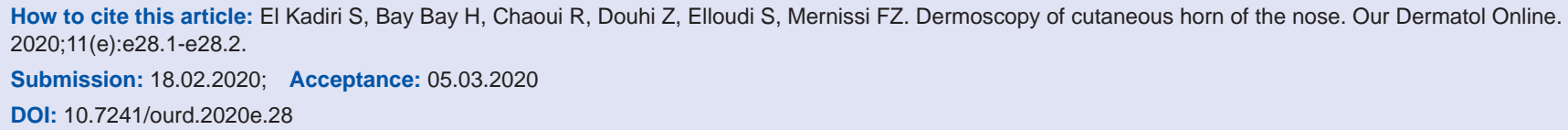




\section{www.odermatol.com}

The authors certify that they have obtained all appropriate patient consent forms. In the form the patient(s) has/have given his/her/their consent for his/her/their images and other clinical information to be reported in the journal. The patients understand that their names and initials will not be published and due efforts will be made to conceal their identity, but anonymity cannot be guaranteed.

\section{REFERENCES}

1. Haddad CJ, Haddad-Lacle JEM. Cutaneous horn: get to the bottom of it. BMJ Case Rep. 2014;2014: pii: bcr2014204447.

2. Jankovic A, Bibic I, Gocev G. Large growth on the face. Cutaneous horn. Am Fam Physician. 2012;86:273-4.

3. Fernandes NF, Sinha S, Lambert WC, Schwartz RA. Cutaneous horn: a potentially malignant entity. Acta Dermatovenerol Alp Panonica Adriat. 2009;18:189-93.

4. Li X. Clinical and dermoscopic features of common warts. J Eur Acad Dermatol Venereol. 2017;31:e308-e310.

Copyright by Selma El Kadiri, et al. This is an open-access article distributed under the terms of the Creative Commons Attribution License, which permits unrestricted use, distribution, and reproduction in any medium, provided the original author and source are credited.

Source of Support: Nil, Conflict of Interest: None declared. 